\title{
Forgotten Masterpieces of Art: Reflections of External and Internal Policy in Fifth Century Greece
}

\begin{abstract}
By Margit Linder ${ }^{*}$
In his Naturalis Historia (34.68) Pliny the Elder refers to the famous Greek artist Telephanes (dated to the first quarter of the 5th century $B C)$, who came from Phocaea, and has worked not only in Greece (Larisa/Thessaly) but also in Persia, for the Great Kings Darius and Xerxes. He also informs us that none of his glorious works of art has been conserved because they were 'concealed' (latuerint) in Thessaly. Some modern researchers have assumed that the meaning of this contradictory passage is as follows: because of the disgraceful fact that one of their countrymen has been engaged by the 'enemy', they decided to hide his works from the eyes of other Greeks and strangers as well. But is such an interpretation possible at all? Is it imaginable that any Greek artist - sculptor, painter or architect - would have been judged as immoral by his own people or even punished as a traitor, just because he offered his services to a hostile patron? The analysis of the ancient text corpus shows that the Greeks distinguished between the sphere of state affairs and arts policy, at least when it was about inner-Greek relations. It seems that artists could work wherever their talent was needed and for whom they wanted to, without limitation. But was the Greek's attitude liberal as well when it concerned art-transfer with the enemy par excellence, namely the Barbarians? Modern scholars have interpreted Pliny's text passage about the sculptor Telephanes as example for the hostile attitude of the Greeks towards those countrymen who created works for the Persian Kingdom. But, by analyzing Pliny's narration on the basis of the historical background of the involved parties (Phocaea, Larisa/Thessaly and the Persian court) it becomes clear that this is not the case at all. The text which appears to be illogical at first glance does make sense when one regards the following connections: the Ionians of Phocaea had tight relations to the Persian kings, shown by their money which was coined in accordance with the Persian standard. Therefor the idea of a Phocaean artist who was commissioned by his city's business partner is not erroneous at all. In addition to it, the relation between the Persian Kingdom and the Thessalian polis of Larisa which existed even before the outbreak of the Persian wars (ca. 500 BC) explains why a Phocaean sculptor should have worked for the
\end{abstract}

*Assistant Professor, Institute for Ancient History, University of Graz, Austria. 
people of Larisa with whom his hometown had no alliance at all. It seems that the talented artist Telephanes was mediated to Larisa by the Persian kings who maintained tight contact with the rulers of this city, namely the Aleuads who acted as heads of the Thessalian League. Following this thesis it becomes clear too why Telephanes' masterpieces of art vanished somewhere along the line: after Iason of Pherae became the League's new ruler about 375 BC the Aleuads lost their power over Larisa and were expelled. These political changes obviously involved the destruction of whatever was connected to the hatred dynasty, who once had assisted the Persians in their plan to subdue the Greeks, and this destructiveness concerned Telephanes' works too. But in the end, it was not the artist who had been prosecuted by his countrymen for collaboration with the Barbarians but his former employers, the Aleuads of Larisa.

The Greek world of the late archaic and classical periods, a time wellknown to us because of the relatively good body of source material available, is designated as a martial one. From the beginning of the conflict between the Ionians and Persians during the Peloponnesian War through to the rise of the Macedonian Empire under Philipp II and Alexander the Great, there are countless reports on every kind of war. On the one hand there were armed conflicts between the Greeks and foreign nations, on the other hand there were those which took place in the context of intrastate disputes. Ancient historians like Herodotus, Xenophon, Diodorus and others give quite explicit information about the background and motives of these wars, along with supplying details about armies, strategies and battle courses. ${ }^{1}$ Some historians, especially Thucydides, report beyond that. In his description of the Peloponnesian War, designated in his own words as the most terrible war of all times (1.23.1), he also specifies the impact - i.e. depopulation, civil war, enslavement etc. - on cities, nations and even individuals. ${ }^{2}$ The picture formed of this war shows in detail how radically life could change when the Greeks fought the Barbarians or when one polis battled against another and fellow countrymen became enemies. As a consequence of wars it often occurred that cities were destroyed, alliances were broken up, former trade relations were (temporary) cut and diplomatic efforts were neglected. ${ }^{3}$ The ancient sources illustrate precisely that times of war could modify the fate of whole towns, as well as the lives of

\footnotetext{
${ }^{1}$ See William Pritchett, The Greek state at war (II) (Berkeley et al.: Californian University Press, 1974), 133-290; William Pritchett, The Greek state at war (IV) (Berkeley et al.: Californian University Press, 1985), 1-93.

${ }^{2}$ For the impact of the Peloponnesian War see Margit Linder, "Die Folgen des Krieges: Untersuchungen zur Arbeitsweise des Thukydides." Diomedes 4, (2007): 69-88 (with full reference).

${ }^{3}$ Cf. Hans-Joachim Gehrke, Stasis: Untersuchungen zu den inneren Kriegen in den griechischen Staaten des 5. und 4. Jahrhunderts v. Chr. (Vestigia) (Munich: Beck, 1985), 208267.
} 
population, in matters of public autonomy of decision (like trade issues) and personal freedom.

Despite these restraints, caused by inner and external conflicts, there is one sphere which was never affected by negative aftermaths, namely art and arts policy. An analysis of archaic and classical artists' activities shows, without exception, that when it came to charges concerning works of art there was absolutely no cutback, neither in public nor in private - a statement which shall be verified hereunder.

Artists like the illustrious sculptors Phidias, Calamis, Myron and Lysippus created masterpieces of art for persons of influence and Greek poleis all over the Mediterranean world. ${ }^{1}$ They were authorized by cities without any problems, regardless of whether they were at war with their home country at the time of the assignment. For example, shortly before the middle of the $5^{\text {th }}$ century BC the famous Boeotian sculptor Calamis produced several statues for Athens, and around this date he also had an appointment with the Spartans for whom he made an image for a dedication at Delphi. ${ }^{2}$ Considering the delicate relations of both parties, ${ }^{3}$ it seems, in political terms, not in the least natural to commission an artist who has just worked for the 'enemy', rather quite the contrary. However, in the case of the artists mentioned above there was absolutely no animosity, first they would be working for one polis, creating the cult-statue of the town-deity, and then they would be engaged by another to make something outstanding that would enlarge the glory of the employer.

One could bring forward the argument that these artists had a special social position because of their celebrity and that this was the reason for being able to work wherever, whenever and for whom they liked. This is not correct, however, because the ancient sources show that what applied to famous men applied to barely-known men as well. Such was the case of the sculptor Antiphanes of Argos who mostly worked at Delphi, where he made a colossal horse for the Argivans in honor of their victory over the Spartans (414 BC). Some years later he was commissioned by the losers to contribute towards creating the so-called Lysandros monument (405 BC). Around 369 BC he was

\footnotetext{
${ }^{1}$ Places of engagements: Phidias of Athens - Pellene (Paus. 7.27.2), Plataea (Paus. 7.27.2), Delphi (Paus. 10.10.1), Megara (Paus. 1.40.4), Thebes (Paus. 9.10.2), Olympia (Paus. 5.10.2), Ephesus (Plin. nat. 34.53); Calamis of Boeotia - Athens (Paus. 1.3.3; 1.23.2; 5.26.6), Olympia (Paus. 5.25.2; 5.26.6; 8.42.8-10), Delphi (Paus. 10.16.4), Apollonia Pontica (Strab. 7.6.1; Plin. nat. 4.92); Myron of Athens - Samos (Strab. 14.1.14), Ephesus (Vitr. 10.2.13; Plin. nat. 34.58), Acragas (Cic. Verr. 4.93), Aegina (Paus. 2.30.2), Messene (Cic. Verr. 4.5), Olympia (Paus. 6.2.2; 6.8.4; 6.8.5; 6.13.2); Lysippus of Sicyon - Argos (Paus. 2.20.3), Delphi (Plin. nat. 34.63-64), Thespiae (Cic. Verr. 2.4.4; Strab. 9.2.25; Paus. 9.27.1-4), Thebes (SEG 13, 349), Thermos (IG I² 1, 52), Pharsalus (IG IX 2, 249), Corinth (Jean Marcadé, Recueil des signatures de sculpteurs grecs (I) (Paris: Librairie E. de Boccard, 1953, 69), Lampsacus (Strab. 13.1.19), Lindos (Plin. nat. 34.63), Cassandreia (Athen. deipn. 11.28.11), Sicyon (Paus. 2.9.6), Tarent (Plin. nat. 34.40).

${ }^{2}$ See previous footnote.

${ }^{3}$ For these conflicts see Ernst Badian, From Plataea to Potidaea: Studies in the History and Historiography of the Pentecontaetia (Baltimore and London: The John Hopkins University Press, 1993), 1-58 and Edmund F. Bloedow, "Why did Sparta rebuff the Athenians at Ithome in 462 B.C.?." Ancient History Bulletin 14 no. 3 (2000): 89-101.
} 
engaged by Argos anew to participate in making a dedication which praised the city's liberation from Spartan control. ${ }^{1}$ Thus, working for the enemy was not an issue because his home town charged him (again), and to the Spartans, who were nearly at all times antagonists of the Argivans, it obviously did not make any difference too. To give another example, the painter Agatharchus of Samos is mentioned in conjunction with the interior decoration of Alcibiades' house at Athens. ${ }^{2}$ The engagement occurred around 440 BC, when the Athenians had massive problems in detaining the Samians, who offered resistance against the Delian League ${ }^{3}$ - a circumstance which did not keep the Athenian politician from hiring a 'public enemy'. When it comes to art policy, it appears to become less 'political'; that is to say, whether to be friend or enemy seemed to be irrelevant. Artists could travel far away and work wherever their talent was needed and, importantly, for whom they wanted, without limitation. ${ }^{4}$

The discussed examples make clear that the Greeks distinguished precisely between the sphere of state affairs and arts policy. The question is whether this behavior was limited to inner-Greek relations. Was the Greek's attitude also liberal if it concerned art-transfer with the enemy par excellence, namely the Barbarians?

Around $500 \mathrm{BC}$ the evidence for Greeks on Persian duty accumulates. It was primarily about mercenary soldiers, physicians, and various specialists like builders. ${ }^{5}$ The texts of Persepolis - i.e. the palace foundation-inscriptions, the

\footnotetext{
${ }^{1}$ For 414 see Paus. 10.9.12; FDelphes III 1, 91 and 573; cf. Thuc. 6.95; for 405: Paus. 10.9.8; for 369: Paus. 10.10.5; FDelphes III 1, 69-78. Cf. Chrissoula Ioakimidou, Die Statuenreihen griechischer Poleis und Bünde aus spätarchaischer und klassischer Zeit. (München: tuduvVerlagsgesellschaft, 1997), 107-119.

${ }^{2}$ Andoc. Alc. 17; Plut. Alc. 16.5 .

${ }^{3}$ Thuc. 1.115.2-117.2; cf. IG I ${ }^{3} 48$.

${ }^{4}$ For the social position and living conditions of ancient artists respectively artisans see Hans Poeschel, "Der Künstler im Spiegel des antiken Schrifttums." Literatur 41, (1938-39): 525528; Hans Lauter, Zur gesellschaftlichen Stellung des bildenden Künstlers in der griechischen Klassik (Erlangen: FAU University Press, 1974), passim; Alison Burford, Künstler und Handwerker in Griechenland und Rom (Mainz: Verlag Philipp von Zabern, 1985), passim; Jan Souček, "Die fremden Künstler und Denker in der athenischen Kultur des 5. Jh. vor u. Z." Listy filologické 110, (1987): 1-10; Hans-Peter Müller, "Die gesellschaftliche Stellung des griechischen bildenden Künstlers im 4. Jahrhundert v. u. Z.” Ethnographisch-archäologische Zeitschrift 29, (1988): 139-145; Hanna Philipp "Handwerker und bildende Künstler in der griechischen Gesellschaft: Von homerischer Zeit bis zum Ende des 5. Jahrhunderts v. Chr." In Polyklet: Der Bildhauer der griechischen Klassik, Ausstellung im Liebighaus - Frankfurt am Main, ed. Herbert Beck et. al., (Mainz: Zabern Verlag, 1990), 79-110.; Thomas Pekáry, "Welcher vernünftige Mensch möchte schon Phidias werden? Das Ansehen des Künstlers im antiken Rom." Boreas 18, (1995): 13-18; Ingomar Weiler, “Künstler-Handwerker' im Altertum - Randseiter der antiken Gesellschaft?." In Komos: Festschrift Thuri Lorenz, ed. Gabriele Erath et al., (Vienna: Phoibos Verlag, 1997), 149-154; Agnes Darab, "Lebensbeschreibungen der berühmtesten Maler, Bildhauer und Architekten. Antike Künstleranekdoten”, Acta Classica 44, (2008): 73-93.

5 See Gerold Walser, "Griechen am Hofe des Großkönigs." In Festgabe zum sechzigsten Geburtstag von H. von Greyerz, ed. Erich Walder et al.,( Bern: Herbert Lang Verlag, 1967), 189-202; Josef Hofstetter, Die Griechen in Persien: Prosopographie der Griechen im Persischen Reich vor Alexander. (Berlin: Reimer Verlag, 1978), 203-207; Bernd Funck,
} 
treasury tablets, the fortification texts and the Greek inscriptions ${ }^{1}-$ and the remains of the sculptural decoration demonstrate that the Persian kings employed a great number of Greek craftsmen and artists to work up their residence at the end of the $6^{\text {th }}$ century. ${ }^{2}$ The Persian texts unfortunately do not mention these people by name but merely by an umbrella term, i.e. Ionians, and by a family token, and they supply no information about the employer's attitude towards the workers either. However, given that the Persians were engaging Greek skilled workers, who usually stayed by choice, ${ }^{3}$ over a period of 40 years, the assumption that the Barbarians appreciated them seems coherent. The Persians as well as the Assyrians and the Babylonians were used to employing people of foreign ethnicities. ${ }^{4}$ They utilised their talent as sculptors and artisans to decorate their magnificent buildings. There was a kind of limitation, however. An analysis of Greek-Achaemenid art shows that the method of fabrication was pure Ionian, whereas style and composition were Persian. Thus, Ionian sculptors were strictly controlled; their one and only task was to produce someone else's design. What these clients were really concerned about was not the nationality but the artistic background of the creators and how they could use their best talents for the glorification of their kingdom. ${ }^{5}$

"Griechen im Perserreich." In Mit Fremden leben: eine Kulturgeschichte von der Antike bis zur Gegenwart, ed. Alexander Demandt et al., (München: C. H. Beck, 1985), 24-36.

${ }^{1}$ These five inscriptions, only containing names, were found at the quarry near Persepolis, dating to the end of the $6^{\text {th }}$ and the beginning of the $5^{\text {th }}$ century BC. The style as well as the names (Pytharchus) indicate Ionian origin. See Michael Roaf, "Texts about Sculptures and Sculptors at Persepolis." Iran 18, (1980): 68.

${ }^{2}$ For this phenomenon see Gisela M. A. Richter, "Greeks in Persia." American Journal of Archaeology 50, (1946): 15-30; Godefroid Goossens, "Artistes et artisans étrangers en perse sous les Achéménides." Nouvelle Clio 1-2, (1949-50): 32-44; Jean-Paul Guépin, "On the Position of Greek Artists under Achaemenid Rule." Persica 1, (1963-64): 34-52; Giovanni P. Caratelli, "Greek inscriptions of the Middle East." East and West 16, (1966): 31-36; Carl Nylander, Ionians in Pasargadae: Studies in Old Persian Architecture. (Uppsala: Almqvist \& Wiksell, 1970), passim and Carl Nylander, "Foreign Craftsmen in Achaemenid Persia." In Memorial Volume of the Vth International Congress of Iranian Art and Archaeology. Tehran, Isfahan, Shiraz, 11th-18th April 1968, Edited by Akbar Tajvidi and Mohammed Y. Kiani. (Tehran: Ministry of Culture and Arts, 1972), 311-318; Muhammad A. Dandamayev, "Politische und wirtschaftliche Geschichte." In Beiträge zur Achämenidengeschichte, ed. Gerald Walser, (Wiesbaden: Steiner Verlag, 1972): 15-58; Michael Roaf, "Texts about Sculptures and Sculptors at Persepolis." Iran 18, (1980): 65-74; Bernd Funk, "Griechen im Perserreich." In Mit Fremden leben: eine Kulturgeschichte von der Antike bis zur Gegenwart, ed. Alexander Demandt et al., (München: C. H. Beck, 1985): 24-36; Georg L. Hoffmann, "Defining identities: Greek artistic interaction with the Near East." In Crafts and images in contact: studies on Eastern Mediterranean art of the first millennium BCE, ed. Claudia E. Suter and Christoph Uehlinger, (Fribourg: University Press, 2005): 351-389.

${ }^{3}$ Cf. Muhammad A. Dandamayev, "Politische und wirtschaftliche Geschichte." In Beiträge zur Achämenidengeschichte, ed. Gerald Walser, (Wiesbaden: Steiner Verlag, 1972): 39-40.

${ }^{4}$ See Michael Roaf, "Texts about Sculptures and Sculptors at Persepolis." Iran 18, (1980): 70. Cf. Diod. 1.46.4 (regarding the transfer of craftsmen from Egypt to Persia for building their residences).

${ }^{5}$ Cf. Gisela M. A. Richter, “Greeks in Persia.” American Journal of Archaeology 50, (1946): $15-25$. 
While the Persian texts do not supply any detailed notes about the artist's or artisan's provenance and working area, there is more (prosopographic) information conveyed by the Greek sources. ${ }^{1}$ Most of these men mentioned were troopers, but there were also Greeks belonging to the high command. Some were working as physicians, even as the king's personal one, like Polycritus of Mende (Plut. Artax. 21.2) and Ctesias of Cnidus (Xen. an. 1.8.26). There was also a great number of athletes, oracle-priests, poets, interpreters, political refugees, like Hipparchus (Lyc. Leocr. 117) and Themistocles (Thuc. 8.45), and political agents who served the Great King. Furthermore, there is evidence of architects, or rather builders, as in the case of Mandrocles of Samos who constructed the bridge over the Bosporus by order of Darius during his operation against the Scythians (514 BC). ${ }^{2}$ Herodotus (4.88) reports that the king was so contented that he overwhelmed Mandrocles with precious gifts. During his campaign against the Greeks (480 BC), king Xerxes employed a so to speak 'hostile' person too, as Harpalus of Tenedus is mentioned as having built the bridge over the Hellespont. ${ }^{3}$ In both cases there is no negative statement or judgment delivered in the Greek sources concerning their choice of clients. Using these examples, it can be determined that the Persian kings commissioned Greek architects because of their outstanding skills, without any reservation, and that the Greeks who decided to work for these employers need not fear any rejection by their countrymen. An analysis of the entire ancient text-corpus shows that there is only one report which could be understood as a counterexample. In the $34^{\text {th }}$ book of his Natural History, Pliny the Elder refers to the following:

'artifices qui compositis voluminibus condidere haec miris laudibus celebrant Telephanem Phocaeum ignotum alias, quoniam in Thessalia habitaverit, et ibi opera eius latuerint, alioqui suffragiis ipsorum aequatur Polyclito, Myroni, Pythagorae. Laudant eius Larisam et Spintharum pentathlum et Apollinem. Alii non hanc ignobilitatis fuisse causam, sed quod se regum Xerxis atque Darei officinis dediderit, existimant.'

'Those sculptors who have written treatises on the subject give high praise to Telephanes of Phokaia, who is otherwise unknown, since, they say, he lived in Thessaly, where his works remained unnoticed. These writers however adjudge him a place beside Polykleitos, Myron and Pythagoras, praising his statues of Larissa, of Spintharos, a winner in the five contests, and of Apollo. Others give a different

\footnotetext{
${ }^{1}$ See Josef Hofstetter, Die Griechen in Persien: Prosopographie der Griechen im Persischen Reich vor Alexander, (Berlin: Reimer Verlag, 1978), 201-209. Cf. Gerold Walser, Hellas und Iran: Studien zu den griechisch-persischen Beziehungen vor Alexander (Darmstadt: Wissenschaftliche Buchgesellschaft, 1984), 20-54.

${ }^{2}$ For this campaign see Hdt. 4.87-89; cf. Polyb. 4.43.

${ }^{3}$ Laterculi Alexandrini, col. 8.8-11; cf. Hdt. 7.33-37; Cens. 18.5; Avien. Arat. 1366-1369.
} 
reason for his comparative obscurity, saying that he passed into the service of king Xerxes and of Dareios.' ${ }^{, 1}$

According to his report, the sculptor Telephanes of Phocaea was mentioned in specialist literature as a distinguished artist, comparable to his famous colleagues Polycletus, Myron and Pythagoras. Although he created masterpieces of art, like the statues of the nymph Larissa, the athlete Spintharus, ${ }^{2}$ and of Apollo, none of his works were conserved. To explain this phenomenon he specifies two proposals for solution, based on the sources he used. First, Telephanes remained almost fameless because he lived and worked in Thessaly, a region which was genuinely not known for art at all, thus the artinterested public loosed sight of his sculptures. Second, he was relatively unknown to his countrymen and hence to art connoisseurs because he decided to work far away from homeland Greece, namely for the Persian kingdom.

Pliny's text passage has brought forth intense discussions within modern research about Telephanes as an artist and person, in particular due, to the discrepancy which arises out of the text at first glance. Some researchers ${ }^{3}$ argued against the translation 'Phocaea', claiming that 'Phocaeum' is just a prosaic variant of 'Phocensis', and so Telephanes originally came from Phocis rather than Phocaea in Asia Minor - a thesis which can be distinctly disproved. Pliny mentions the Ionian city Phocaea twice; first, when he refers to the foundation of Massalia and second when he gives an account of the Ionian region itself. ${ }^{4}$ In this connection he uses the terms 'Phocaeensium' and 'Phocaeum', whereas he utilises the words 'Phocensium' and 'Phocis' when he reports on the mainland Greece region. ${ }^{5}$ So it is safe to say that according to Pliny, Telephanes 'Phocaeus' was of Ionian origin.

The main problem related to this text passage is the apparent incoherency. Pliny wants to explain the obscurity of Telephanes' awareness level. Therefore, he uses two different kinds of written records. ${ }^{6}$ Some authors have mentioned that Telephanes, although of Phocaean origin, acted as a sculptor in Thessaly an absolute surety, given that he created a statue of the nymph Laris(s)a ${ }^{7}$ who

\footnotetext{
${ }^{1}$ Plin. nat. 34.68 , trans. by Katharine Jex-Blake and Eugenie Sellers, The Elder Pliny's Chapters on the History of Art (Chicago: Argonaut Inc. Publishers, 1968).

${ }^{2}$ Solely mentioned by Pliny.

${ }^{3}$ See Susanne Lavva, "Telephanes Phoceus." In Hellas und der griechische Osten: Studien zur Geschichte und Numismatik der griechischen Welt, ed. Walter Leschhorn et al., (Saarbrücken: SDV Saarbrücker Druckerei und Verlag GmbH, 1996): 66; cf. Michael Roaf, "Texts about Sculptures and Sculptors at Persepolis." Iran 18, (1980): 65-74.;

${ }^{4}$ Plin. nat. $3.45 ; 5.119$.

${ }^{5}$ Plin. nat. $3.72 ; 4.1 ; 4.7 ; 4.27 ; 18.215$.

${ }^{6}$ For the sources used by Pliny for his chapters on art (mainly Xenocrates of Athens and Antigonus of Carystus) see August Kalkmann, Die Quellen der Kunstgeschichte des Plinius (Berlin: Weidmannsche Buchhandlung, 1898) and Katharine Jex-Blake and Eugenie Sellers, The Elder Pliny's Chapters on the History of Art (Chicago: Argonaut Inc. Publishers, 1968).

${ }^{7}$ The nymph and the toponym are mentioned as Larissa or Larisa, see Katerini Liampi, "Larisa." Lexicon Iconographicum Mythologiae Classicae VI 1, (1992): 213 and Thomas H. Nielsen, "Thessalia and Adjacent Regions" In Inventory of Archaic and Classical Poleis, ed. Mogens H. Hansen and Thomas H. Nielsen, (Oxford: University Press, 2004): 695; cf. Ernst
} 
was eponymous for the Thessalian city of Larisa, something that fits with his Apollo statue too because Apollo (Kerdoios) was the town's main deity. ${ }^{1}$ So it is conveyed by several writers that Telephanes of Phocaea worked in Thessaly and considering the themes of his charges, he mainly acted at Larisa.

Notwithstanding, there must have been authors who narrated something else because Telephanes is mentioned as a service provider for the Persian kings. ${ }^{2}$ Now, which of both explanatory models is accurate? Was Telephanes been a quasi unknown to intellectual circles because he worked in the 'artistic back-country' of Greece or because he resolved to act as a sculptor for the Persian kingdom?

At first glance these two notes as well as the whole text itself appear contradictory. Modern scholars ${ }^{3}$ have explained and eliminated this discrepancy as follows: Telephanes worked in Thessaly, where his masterpieces of art were hidden from the public when it came out that he was employed by the enemy par excellence, namely the Barbarians. According to this thesis, the artist's countrymen were ashamed of him, convicted him of his former actions and thus tried to delete him and his work from memory. Following this, Pliny's text would be the one (and only) passage which demonstrates that artists were not free in choosing their employers as soon as the clients were Persians. However, is this really the case? Considering the

Langlotz, "Die Larisa des Telephanes. Museum Helveticum 8, (1951): 157-170 and Ernst Langlotz, "Zur Deutung der Penelope." Jahrbuch des Deutschen Archäologischen Instituts 76, (1961): 72-99; Hedwig Kenner, "Die Trauernde von Persepolis." Wiener Studien 79, (1966): 572-592; Werner Gauer, "Penelope, Hellas und der Perserkönig: ein hermeneutisches Problem." Jahrbuch des Deutschen Archäologischen Instituts 105, (1990): 31-56; Klaus Stähler, "Die Freiheit in Persepolis? Zum Statuentypus der sog. Penelope." Boreas 13, (1990): $5-12$.

${ }^{1}$ See Thomas H. Nielsen, "Thessalia and Adjacent Regions." In Inventory of Archaic and Classical Poleis, ed. Mogens H. Hansen and Thomas H. Nielsen, (Oxford: University Press, 2004): 696.

${ }^{2}$ The fact that the kings are not listed in chronological order is not an issue (cf. Robert Fleischer, "Ein Bildhauerauftrag unter Dareios II." Archäologischer Anzeiger, (1983): 33-37 and Susanne Lavva, "Telephanes Phoceus." In Hellas und der griechische Osten: Studien zur Geschichte und Numismatik der griechischen Welt, ed. Walter Leschhorn et al., (Saarbrücken: SDV Saarbrücker Druckerei und Verlag GmbH, 1996), 73-75. Pliny (or rather his sources) evidently meant the famous kings of the Persian Wars, Darius I and his son Xerxes I. It is hardly imaginable that he considered Xerxes II (424) and Darius II (424-405), since Xerxes reigned for only 45 days (Diod. 12.64.1) so who would remember this insignificant king? See also Katherine Jex-Blake and Eugenie Sellers, The Elder Pliny`s Chapters on the History of Art, (Chicago: Argonaut Inc. Publishers, 1968), 54 n. 7: "The names of Xerxes [...] and of Dareios [...] are apparently only introduced to attach the statement to well-known names. The dates are plainly irreconcilable." Cf. Wolfgang Fischer-Bossert, "Review of: St. Lavva, Die Münzprägung von Pharsalos." Numismatic Chronicle 163, (2003): 2-3.

${ }^{3}$ See Apostolos S. Arvanitopoulos, "Thessalikai epigraphai." Archaiologike Ephemeris, (1916): 19-21; Hanna Philipp, "Handwerker und bildende Künstler in der griechischen Gesellschaft: Von homerischer Zeit bis zum Ende des 5. Jahrhunderts v. Chr." In Polyklet: Der Bildhauer der griechischen Klassik, Ausstellung im Liebighaus - Frankfurt am Main, ed. Herbert Beck et. al (Mainz: Zabern Verlag, 1990), 95; and Susanne Lavva, "Telephanes Phoceus." In Hellas und der griechische Osten: Studien zur Geschichte und Numismatik der griechischen Welt, ed. Walter Leschhorn et al., (Saarbrücken: SDV Saarbrücker Druckerei und Verlag GmbH, 1996), 72 . 
political history behind the topographical information mentioned above, that is to say Phocaea as the artist's origin and Thessaly respectively Larisa, plus the Persian Empire as the location of activity, another possible interpretation arises which can eliminate potential ambiguities and annihilate the apparent innertextual discrepancy as well.

First of all, there is no reason for having doubts about the compatibility of Pliny's two statements concerning Telephanes' employers. In fact they should be recognised as unifying because one piece of information only makes sense in connection with the other. At first sight there is no special cause for the engagement of a Phocaean sculptor at Larisa. The ancient sources as well as the archaeological evidence do not offer any indication of a tightknit relationship between these two cities, neither in diplomatic nor in trade terms. Whereas the contact between the Ionian polis and the Persian kingdom is not altogether surprising. Phocaea was captured by Harpagus under the rule of Cyrus II during his war against the Lydians (about 546 BC). The polis was partially destroyed, for which reason many inhabitants ${ }^{1}$ left their city and sailed to Cyrnus (Corsica) where they had founded Alalia twenty years before. ${ }^{2}$ The remains of the population rebuilt the town and as the numismatic evidence as well as the ceramic finds show, the city flourished economically. Phocaean coins and ceramics were found in throughout Ionia and up to Persepolis. ${ }^{3}$ From the middle of the $6^{\text {th }}$ century to the end of the Persian wars, assigned to the battle of the Eurymedon (about 465 BC) and with a short break during the Ionian Revolt, ${ }^{4}$ Phocaea was ruled by a tyrant, deployed by grace of the Persian king (Hdt. 4.138.8). ${ }^{5}$ With regard to the political background it is absolutely understandable that a talented Phocaean artist like Telephanes could have been employed by his sovereigns Darius and Xerxes, or rather their satraps. Due to his relationship with the Persians, it now becomes clear why he would have worked at Larisa at all.

The royal house of the Aleuads, who temporary acted as Tagi of the Thessalian League, held sway over Larisa. ${ }^{6}$ These dynasts had tightknit

\footnotetext{
${ }^{1}$ Herodotus' account (1.164), whereupon all of the inhabitants left the city, is not reliable. It is barely imaginable that a mass evacuation of a city could have taken place during the course of one day (cf. Antiochus of Syracus FGrHist 555 F 8). See Oswin Murray and Alfonso Moreno, ed. A Commentary on Herodotus: Books I-IV. (Oxford: University Press, 2007): 185.

${ }^{2}$ Hdt. 1.164-165. See Stephen Mitchell, “Archaeology in Asia Minor 1990-98", Archaeological Reports 45, (1999): 125-191.

${ }^{3}$ For the special economic role of Phocaea in connection with the Persian Empire see Ernst Langlotz, Die kulturelle und künstlerische Hellenisierung der Küsten des Mittelmeeres durch die Stadt Phokaia, (Köln: Westdeutscher Verlag, 1966), 25-29.

${ }^{4}$ Hdt. 6.8.2; 6.11-12; 6.17. After 465 BC Phocaea became a member of the Delian League. See Michael M. Austin, "Greek tyrants and the Persians, 546-479 B.C." Classical Quarterly 40, (1990): 289-306 and Lene Rubinstein, "Ionia", In Inventory of Archaic and Classical Poleis, ed. Mogens H. Hansen and Thomas H. Nielsen, 1053-1107, (Oxford: University Press, 2004), 1090 (No. 859).

${ }^{5}$ Cf. Josef Hofstetter, Die Griechen in Persien: Prosopographie der Griechen im Persischen Reich vor Alexander. (Berlin: Reimer Verlag 1978), 114 (No. 191: Laodamas).

${ }^{6}$ For the history and political function of the Aleuads see Johannes Toepffer, "Aleuadai." RE I, (1894): 1372-1374.
} 
contacts with the Persian Empire even before the outbreak of the great war, represented by the money of Larisa which was coined in accordance with the Persian standard - a unique practice compared to the rest of Greece. ${ }^{1}$ Furthermore, Herodotus (7.6) reports that the Aleuads sent an embassy to king Xerxes to request him to wage war against the Greeks. They complied at the same moment when the Persians appeared. ${ }^{2}$ The Aleuad Thorax and his brothers even accompanied the campaign of Mardonius (9.1). ${ }^{3}$

The ancient sources demonstrate the special relationship between the rulers of Larisa and the Persian kingdom. It is quite imaginable that Telephanes was mediated to the Aleuads to create statues of the town's deity and the eponymous nymph because of the satisfying performance he achieved under the reign of Darius and Xerxes. This thesis fits with the coins of Larisa, which give an account of the statuesque image of the nymph, arising at the first quarter of the $5^{\text {th }}$ century and continuing till the fourth century. ${ }^{4}$ The only openopen-ended question that remains is why Telephanes and his works were known in the specialist literature Pliny used (otherwise we were not aware of anything) but not to the art connoisseurs of his time. It actually seems that his masterpieces of art vanished, as was mentioned above. However, as the historical background verifies, this was not because his countrymen convicted him of acting for the Persians but rather because his works at Larisa were commissioned pieces of the traitors.

After the Persian Wars the Aleuad dynasty lost most of their power but remained ruling at Larisa, ${ }^{5}$ until Iason of Pherae became head of Thessaly about 375 BC (Xen. hell. 6.1.8-10). Five years later, under the leadership of his brother Polyphron, the Aleuads were finally expelled and Larisa received a

\footnotetext{
${ }^{1}$ See Henry D. Westlake, "The Medism of Thessaly." Journal of Hellenic Studies 56, (1936): 12-24 and Neil Robertson, "The Thesselian expedition of 480 B. C." Journal of Hellenic Studies 96, (1976): 102-119.

${ }^{2}$ Hdt. 7.172; Paus. 7.10.2. For the medism of the Aleuads see Henry D. Westlake, "The Medism of Thessaly." Journal of Hellenic Studies 56, (1936): 12-24; Gorgios A. Papantonios, "Ho medismos tōn Thessalōn, tōn Boiotōn kai tōn Phokeōn." Platon 8, (1956): 18-30; Dolores Hegyi, Medismos: Perserfreundliche Richtungen in Griechenland 508-479 v. u. Z. (Budapest: Akademie Verlag, 1974), 39-48; Neil Robertson, "The Thesselian expedition of 480 B.C." Journal of Hellenic Studies 96, (1976): 100-120; Daniel Gillis, Collaboration with the Persians. (Wiesbaden: Franz Steiner Verlag, 1979): 59-74; David F. Graf, Medism: Greek collaboration with Achaemenid Persia. (Ann Arbor: University of Michigan Press, 1979), 6370; Hans-Joachim Gehrke, Stasis: Untersuchungen zu den inneren Kriegen in den griechischen Staaten des 5. und 4. Jahrhunderts v. Chr. (München: C. H. Beck, 1985), 184-197; Arthur Keaveney, "The Medisers of Thessaly." Eranos 93, (1995): 30-38.

${ }^{3}$ For Thorax see Hdt. 7.6; 9.58; cf. Josef Hofstetter, Die Griechen in Persien: Prosopographie der Griechen im Persischen Reich vor Alexander. (Berlin: Reimer Verlag, 1978), 178-179 (No. 314).

${ }^{4}$ See Fritz Herrmann, "Die Silbermünzen von Larissa in Thessalien." Zeitschrift für Numismatik 35, (1925): 1-69 and Katerini Liampi, "Larisa." Lexicon Iconographicum Mythologiae Classicae VI 1, (1992): 213-216.

${ }^{5}$ At the outbreak of the Peloponnesian War they had to defeat a coup (Thuc. 2.22) and in 404 BC the Aleuad Medius resisted Lycophron of Pherae, who tried to become leader of Thessaly and of Larisa (Diod. 14.82; cf. Xen. hell. 4.3.3-5). See Johannes Toepffer, "Aleuadai." RE I, (1894): 1373-1374.
} 
garrison (Xen. hell. 6.4.34). Although the Aleuads obtained an intervention, first by Alexander II and then by Philipp II of Macedon, their original position of power was lost beyond control. ${ }^{1}$ It appears plausible that after the hated dynasty's influence was broken, whatever was connected to it was removed, which unfortunately included Telephanes' works. $^{2}$ In the end, however, it was not the artist who was prosecuted by his countrymen for collaboration with the enemy but his employers, the Aleuads. They bore the blame for the fact that almost all of the Greeks put down the Thessalian people as traitors, a reputation that adhered forever.

In summary, there is no evidence of any kind of limitation concerning artists' mobility or employment policy. According to literary, epigraphic and numismatic sources it can be determined that: inasmuch as their skills were favoured and needed, artists were entirely free to choose their location of engagement as well as the employer, independent of their awareness level and the political background.

\section{References}

Arvanitopoulos, Apostolos S. "Thessalikai epigraphai." Archaiologike Ephemeris, (1916): 17-33.

Austin, Michael M. "Greek tyrants and the Persians, 546-479 B.C." Classical Quarterly 40, (1990): 289-306.

Badian, Ernst. From Plataea to Potidaea: Studies in the History and Historiography of the Pentecontaetia. Baltimore and London: The John Hopkins University Press, 1993.

Bloedow, Edmund F. "Why did Sparta rebuff the Athenians at Ithome in 462 B.C.?." Ancient History Bulletin 14 no.3, (2000): 89-101.

Burford, Alison. Künstler und Handwerker in Griechenland und Rom. Mainz: Verlag Philipp von Zabern, 1985.

Caratelli, Giovanni P. "Greek inscriptions of the Middle East." East and West 16, no.1-2 (1966): 31-36.

Dandamayev, Muhammad A. "Politische und wirtschaftliche Geschichte." In Beiträge zur Achämenidengeschichte, Edited by Gerald Walser. Wiesbaden: Steiner Verlag, 1972, 15-58.

Darab, Agnes. "Lebensbeschreibungen der berühmtesten Maler, Bildhauer und Architekten. Antike Künstleranekdoten.” Acta Classica 44, (2008): 73-93.

Fischer-Bossert, Wolfgang. "Review of: St. Lavva, Die Münzprägung von Pharsalos." Numismatic Chronicle 163, (2003): 399-405.

Fleischer, Robert. "Ein Bildhauerauftrag unter Dareios II." Archäologischer Anzeiger, (1983): 33-37.

\footnotetext{
${ }^{1}$ Diod. 15.61.5; 15.67.4; 15.80.1; 16.35.4; 16.37.3. See Hans-Joachim Gehrke, Stasis: Untersuchungen zu den inneren Kriegen in den griechischen Staaten des 5. und 4. Jahrhunderts v. Chr. ( München: C. H. Beck, 1985), 190-197.

${ }^{2} \mathrm{Cf}$. the approach of Aratus of Sicyon (271-213 BC) who ordered the destruction of the images of the tyrants he had expelled from his hometown (Plut. Arat. 13.1-6). In the year 200 BC Philipp V of Macedon besieged Athens. As a consequence, the inhabitants decided to annihilate all of the monuments erected to compliment the king and his ancestors (Liv. 31.44.4-5; cf. Dio Chrys. 36.41).
} 
Funck, Bernd. "Griechen im Perserreich." In Mit Fremden leben: eine Kulturgeschichte von der Antike bis zur Gegenwart, Edited by Alexander Demandt et al., München: C. H. Beck, 1985, 24-36.

Gauer, Werner. "Penelope, Hellas und der Perserkönig: ein hermeneutisches Problem." Jahrbuch des Deutschen Archäologischen Instituts 105, (1990): 3165.

Gehrke, Hans-Joachim. Stasis: Untersuchungen zu den inneren Kriegen in den griechischen Staaten des 5. und 4. Jahrhunderts v. Chr. München: C. H. Beck, 1985.

Gillis, Daniel. Collaboration with the Persians. Wiesbaden: Franz Steiner Verlag, 1979.

Goossens, Godefroid. "Artistes et artisans étrangers en perse sous les Achéménides." Nouvelle Clio 1-2, (1949-50): 32-44.

Graf, David F. Medism: Greek collaboration with Achaemenid Persia. Ann Arbor: University of Michigan Press, 1979.

Guépin, Jean-Paul. "On the Position of Greek Artists under Achaemenid Rule." Persica 1, (1963-64): 34-52.

Hegyi, Dolores. Medismos: Perserfreundliche Richtungen in Griechenland 508-479v. u. Z. Budapest: Akademie Verlag, 1974.

Herrmann, Fritz. "Die Silbermünzen von Larissa in Thessalien." Zeitschrift für Numismatik 35, (1925): 1-69.

Hoffmann, Georg L. "Defining identities: Greek artistic interaction with the Near East." In Crafts and images in contact: studies on Eastern Mediterranean art of the first millennium BCE, Edited by Claudia E. Suter and Christoph Uehlinger, Fribourg: University Press, 2005, 351-389.

Hofstetter, Josef. Die Griechen in Persien: Prosopographie der Griechen im Persischen Reich vor Alexander. Berlin: Reimer Verlag, 1978.

Ioakimidou, Chrissoula. Die Statuenreihen griechischer Poleis und Bünde aus spätarchaischer und klassischer Zeit. München: tuduv-Verlagsgesellschaft, 1997.

Jex-Blake, Katharine and Eugenie Sellers. The Elder Pliny's Chapters on the History of Art. Chicago: Argonaut Inc. Publishers, 1968.

Kalkmann, August. Die Quellen der Kunstgeschichte des Plinius. Berlin: Weidmannsche Buchhandlung, 1898.

Keaveney, Arthur. "The Medisers of Thessaly." Eranos 93, (1995): 30-38.

Kenner, Hedwig. "Die Trauernde von Persepolis." Wiener Studien 79, (1966):572592.

Langlotz, Ernst. "Die Larisa des Telephanes. Museum Helveticum 8, (1951): 157-170.

Langlotz, Ernst. "Zur Deutung der » Penelope «." Jahrbuch des Deutschen Archäologischen Instituts 76, (1961): 72-99.

Langlotz, Ernst. Die kulturelle und künstlerische Hellenisierung der Küsten des Mittelmeeres durch die Stadt Phokaia. Köln: Westdeutscher Verlag, 1966.

Lauter, Hans. Zur gesellschaftlichen Stellung des bildenden Künstlers in der griechischen Klassik. Erlangen: FAU University Press, 1974.

Lavva, Susanne. "Telephanes Phoceus." In Hellas und der griechische Osten: Studien zur Geschichte und Numismatik der griechischen Welt, Edited by Walter Leschhorn et al., Saarbrücken: SDV Saarbrücker Druckerei und Verlag GmbH, 1996, 66-77.

Liampi, Katerini. "Larisa." Lexicon Iconographicum Mythologiae Classicae VI 1, (1992): 213-216.

Linder, Margit. "Die Folgen des Krieges: Untersuchungen zur Arbeitsweise des Thukydides." Diomedes 4, (2007): 69-88. 
Marcadé, Jean. Recueil des signatures de sculpteurs grecs (I). Paris: Librairie E. de Boccard, 1953.

Mitchell, Stephen. "Archaeology in Asia Minor 1990-98." Archaeological Reports 45, (1999): 125-191.

Müller, Hans-Peter. "Die gesellschaftliche Stellung des griechischen bildenden Künstlers im 4. Jahrhundert v. u. Z." Ethnographisch-archäologische Zeitschrift 29, (1988): 139-145.

Murray, Oswin and Alfonso Moreno, eds. A Commentary on Herodotus: Books I-IV. Oxford: University Press, 2007.

Nielsen, Thomas H. "Thessalia and Adjacent Regions." In Inventory of Archaic and Classical Poleis, Edited by Mogens H. Hansen and Thomas H. Nielsen. Oxford: University Press, (2004), 676-731.

Nylander, Carl. Ionians in Pasargadae: Studies in Old Persian Architecture. Uppsala: Almqvist \& Wiksell, 1970.

Nylander, Carl. "Foreign Craftsmen in Achaemenid Persia." In The Memorial Volume of the $V^{\text {th }}$ International Congress of Iranian Art and Archaeology. Tehran, Isfahan, Shiraz, $11^{\text {th }}-18^{\text {th }}$ April 1968, Edited by Akbar Tajvidi and Mohammed Y. Kiani. Tehran: Ministry of Culture and Arts, 1972, 311-318.

Papantonios, Gorgios A. "Ho medismos tōn Thessalōn, tōn Boiotōn kai tōn Phokeōn." Platon 8, (1956): 18-30.

Pekáry, Thomas. "Welcher vernünftige Mensch möchte schon Phidias werden? Das Ansehen des Künstlers im antiken Rom." Boreas 18, (1995): 13-18.

Philipp, Hanna. "Handwerker und bildende Künstler in der griechischen Gesellschaft: Von homerischer Zeit bis zum Ende des 5. Jahrhunderts v. Chr." In Polyklet: Der Bildhauer der griechischen Klassik, Ausstellung im Liebighaus - Frankfurt am Main, edited by Herbert Beck et. al.. Mainz: Zabern Verlag, 1990, 79-110.

Poeschel, Hans. "Der Künstler im Spiegel des antiken Schrifttums." Literatur 41, (1938-39): 525-528.

Pritchett, William K. The Greek state at war (II). Berkeley et al. Californian University Press, 1974.

Richter, Gisela M. A. "Greeks in Persia." American Journal of Archaeology 50, (1946): 15-30.

Roaf, Michael. "Texts about Sculptures and Sculptors at Persepolis." Iran 18, (1980): 65-74.

Robertson, Neil. "The Thesselian expedition of 480 B. C." Journal of Hellenic Studies 96, (1976): 100-120.

Rubinstein, Lene. "Ionia". In Inventory of Archaic and Classical Poleis, Edited by Mogens H. Hansen and Thomas H. Nielsen. Oxford: University Press, 2004, 1053-1107.

Souček, Jan. "Die fremden Künstler und Denker in der athenischen Kultur des 5. Jh. vor u. Z." Listy filologické 110, (1987): 1-10.

Stähler, Klaus. "Die Freiheit in Persepolis? Zum Statuentypus der sog. Penelope." Boreas 13, (1990): 5-12.

Toepffer, Johannes. “Aleuadai.” RE I, (1894):1372-1374.

Walser, Gerold. "Griechen am Hofe des Großkönigs." In Festgabe zum sechzigsten Geburtstag von H. von Greyerz, Edited by Erich Walder et al. Bern: Herbert Lang Verlag, 1967, 189-202.

Walser, Gerold. Hellas und Iran: Studien zu den griechisch-persischen Beziehungen vor Alexander. Darmstadt: Wissenschaftliche Buchgesellschaft, 1984. 
Vol. 1, No. $1 \quad$ Linder: Forgotten Masterpieces of Art: Reflections of External...

Weiler, Ingomar. "Künstler-Handwerker' im Altertum - Randseiter der antiken Gesellschaft?." In Komos: Festschrift Thuri Lorenz, Edited by Gabriele Erath et al. Vienna: Phoibos Verlag, 1997, 149-154.

Westlake, Henry D. "The Medism of Thessaly." Journal of Hellenic Studies 56, (1936): 12-24. 